\title{
Description of two new species of Sycorax Curtis (Diptera, Psychodidae, Sycoracinae) from the Atlantic Rain Forest of Espírito Santo, Brazil
}

\author{
Claudiney Biral dos Santos $^{1}$ \& Freddy Bravo ${ }^{2,3}$ \\ ${ }^{1}$ Unidade de Medicina Tropical, Universidade Federal do Espírito Santo - UFES, \\ Av. Marechal Campos, 1468, CEP 29040-090, Vitória, ES, Brasil \\ ${ }^{2}$ Departamento de Ciências Biológicas, Universidade Estadual de Feira de Santana - UEFS, \\ Av. Universitária, s/n, 44031-460, Feira de Santana, BA, Brasil \\ ${ }^{3}$ Corresponding author: Freddy Bravo, e-mail: freddy11bravo@yahoo.com.br
}

SANTOS, C.B. \& BRAVO, F. Description of two new species of Sycorax Curtis (Diptera, Psychodidae, Sycoracinae) from the Atlantic Rain Forest of Espírito Santo, Brazil. Biota Neotrop., 9(2): http://www. biotaneotropica.org.br/v9n2/en/abstract?article+bn00309022009.

Abstract: Two new species of Sycorax Curtis from the Atlantic Rain Forest of Espírito Santo, S. cariacicaensis Santos \& Bravo sp. nov. and S. espiritosantensis Santos \& Bravo sp. nov., are described and illustrated.

Keywords: Dipterous, Moth-fly, Southeastern Brazil.

SANTOS, C.B. \& BRAVO, F. Descrição de duas espécies novas de Sycorax Curtis (Diptera, Psychodidae, Sycoracinae) da Mata Atlântica do Espírito Santo, Brasil. Biota Neotrop., 9(2): http://www.biotaneotropica. org.br/v9n2/pt/abstract?article+bn00309022009.

Resumo: Duas espécies novas de Sycorax Curtis da Floresta Atlântica do Espírito Santo, S. cariacicaensis Santos \& Bravo sp. nov. e S. espiritosantensis Santos \& Bravo sp. nov., são descritas e desenhadas.

Palavras-chave: Dípteros, Psicodídeos, Sudeste do Brasil. 


\section{Introduction}

The genus Sycorax Curtis comprises 10 species in the Neotropical region (Barretto 1956, Duckhouse 1972, Young 1979, Bravo 2003, 2007, Bejarano et al. 2008) and four of them are from Brazil: S. assimilis Barretto, 1956 and S. satchelli Barretto, 1956 from São Paulo State (Barretto 1956), S. bahiensis Bravo, 2003 from Bahia State (Bravo 2003), and S. longispinosa Bravo, 2007 from Pará State (Bravo 2007). During routine entomological vigilance studies to control leshmaniasis in the municipality of Cariacica, Espírito Santo State, Brazil, between October 2007 and January 2008, specimens of two new species of Sycorax Curtis were collected and are described here.

\section{Material and Methods}

The specimens studied were collected with CDC light traps and preserved in alcohol $70 \%$. All the specimens were treated with $10 \%$ $\mathrm{KOH}$ and mounted in Berlese's medium according method proposed by Barretto \& Coutinho (1940). Morphological terminology follows that of McAlpine (1981) to Diptera. The specific morphological terminology for Psychodidae follows that of Duckhouse (1990) and Bravo $(2006,2007)$. The specimens were deposited in the Coleção Entomologia da Unidade de Medicina Tropical da Universidade Federal do Espírito Santo, Brazil (CEUMT) and Coleção Entomológica do Museu de Zoologia da Universidade Estadual de Feira de Santana, Feira de Santana, Bahia, Brazil (MZUEFS).

\section{Results}

1. Sycorax cariacicaensis Santos \& Bravo sp. nov. (Figures 1-8)

Type Material. BRAZIL, Espírito Santo, Cariacica, Estação Biológica Duas Bocas, $20^{\circ} 28^{\prime} \mathrm{S}$ and $40^{\circ} 46^{\prime} \mathrm{W}, 15 . X .2007$, Israel de Souza Pinto col., holotype male (CEUMT). Paratypes: 1 male, same locality, date and collector as holotype (CEUMT), 2 males, idem, 06.I.2008 (CEUMT), 3 males, idem, 21.I.2008 (CEUMT), 1 male, idem, 07.V.2008 (CEUMT), 4 males, idem, 19.VI.2008 (CEUMT), 4 males, idem, 21.I.2008 (MZUEFS).

Etymology: The specific name cariacicaensis is based on the type locality.

Diagnosis: First flagellomere $1.5 \mathrm{X}$ the length of the second; gonostylus with a long, thick apical spine-like bristle approximately the same length as the gonostylus; paramere with apical pilosity and a long, thick bristle the same length as the paramere; aedeagal apodeme with a truncate anterior margin.

Description: Male. Head: subcircular in frontal view; eyes separated; labrum triangular; clypeus rectangular $0.5 \mathrm{X}$ the length of the labrum (Figure 1). Antenna with 13 flagellomeres; scape pyramidal, smaller than the pedicel (Figure 1); pedicel spherical (Figure 1); basal flagellomeres cylindrical; first flagellomere 1.5X the length of the second (Figure 2); last flagellomere smaller than twelfth flagellomere; apical apiculus separated from the last flagellomere (Figure 3); ascoids present in flagellomeres 1-3 (Figure 2). Palpus with 4 articles; relative length of palpomeres 1.0:0.8:0.8:0.7 (Figure 4). Wing (Figure 5) with Sc reaching the $\mathrm{C}$ vein; r-m short; $\mathrm{m}-\mathrm{m}$ absent. Epandrium 2.3X wider than long (Figure 6); cerci longer than wide with apical micropilosity (Figure 6). Sternite 10 shorter than the cercus, with rounded apex and apical micropilosity (Figure 6). Gonocoxite pilose, cylindrical, 1.2X the length of the gonostylus; gonocoxites fused basally with hypandrium (Figure 7). Gonostylus pilose with a long subapical bristle and a spine-like bristle at the apex (Figure 7); spine-like bristle similar in length to gonostylus (Figure 7). Paramere long, approximately the same length as the gonocoxite (Figure 7); paramere with apical pilosity and a long, thin subapical bristle $0.7 \mathrm{X}$ the length of the paramere (Figure 8). Aedeagus bifid (Figure 7). Aedeagal apodeme the same

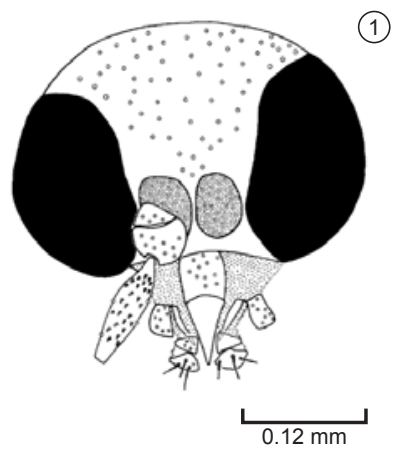

(2)

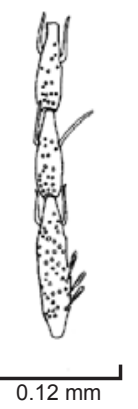

(6)

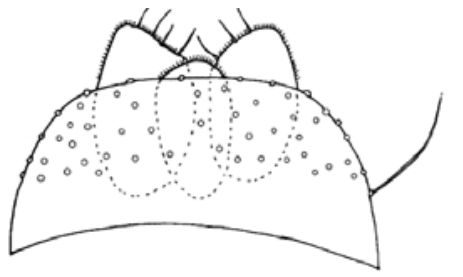

$0.12 \mathrm{~mm}$
(3)
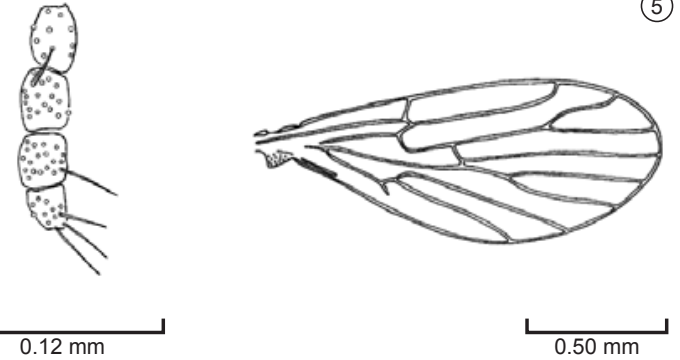

(8)

(7)

(5)
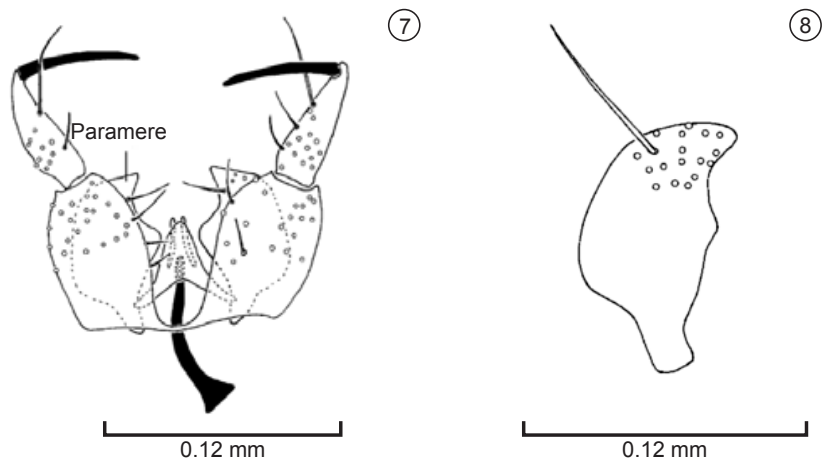

Figures 1-8. Sycorax cariacicaensis Santos \& Bravo sp. nov. Male. Figures 1, 4, 8 from holotype; figures 2, 3, 5-7 from paratypes. 1. Head, frontal. 2. Antenna, flagellomeres 1-3. 3. Antenna, flagelomeres 10-13. 4. Palpus. 5. Wing. 6. Male terminalia, dorsal view. 7. Male terminalia, ventral view. 8. Paramere.

Figuras 1-8. Sycorax cariacicaensis Santos \& Bravo sp. nov. Macho. Figuras 1, 4, 8 do holótipo; figuras 2, 3, 5-7 de parátipos. 1. Cabeça. 2. Antena, flagelômeros 1-3. 3. Antena, flagelômeros 10-13. 4. Palpo. 5. Asa. 6. Terminália masculina, vista dorsal. 7. Terminália masculina,vista ventral. 8. Parâmero. 
length as the paramere, expanded apically, with anterior margin truncate (Figure 7).

Sycorax espiritosantensis Santos \& Bravo sp. nov. (Figures 9-15)

Type material: BRAZIL, Espírito Santo, Cariacica, Estação Biológica Duas Bocas, 20² $8^{\prime} \mathrm{S}$ and $40^{\circ}$ 46' W, 15.VIII.2007, Israel de Souza Pinto col., holotype male (CEUMT). Paratypes: 2 males, same locality and collector as holotype, 06.I.2008 (CEUMT); 1 male, idem, 21.I.2008 (CEUMT); 2 males, idem, 07.V.2008 (CEUMT); 3 males, idem, 19.VI.2008 (CEUMT); 4 males, idem, 21I.2008 (MZUEFS).

Etymology: The specific name espiritosantensis is based on the State where the species was collected.

Diagnosis: First flagellomere 2.0X the length of the second; gonostylus with thick apical spine-like bristle, $0.7 \mathrm{X}$ the length of the gonostylus; paramere with apical pilosity and a long, thin, medial bristle, $0.3 \mathrm{X}$ the length of paramere; distal margin of paramere U-shaped; aedeagal apodeme with a rounded anterior margin.

Description: Head: subcircular in frontal view; eyes separated; labrum triangular; clypeus rectangular $0.8 \mathrm{X}$ the length of the labrum (Figure 9). Antenna incomplete in all specimens studied; scape pyramidal, smaller than pedicel (Figure 9); pedicel spherical (Figure 9); basal flagellomeres cylindrical; first flagellomere 2.0X length of the second (Figure 10); ascoids present in flagellomeres 1-3 (Figure 10). Palpus with 4 articles; relative length of palpomeres 1.0:0.8:0.7:0.7 (Figure 11). Wing (Figure 12) with $\mathrm{Sc}$ reaching the $\mathrm{C}$ vein; $\mathrm{r}-\mathrm{m}$ short; $\mathrm{m}-\mathrm{m}$ absent. Epandrium
1.4X wider than long (Figure 13); cerci longer than wide, with apical micropilosity (Figure 13). Sternite 10 shorter than the cercus, with rounded apex and apical micropilosity (Figure 13). Gonocoxite pilose, cylindrical, 1.4X the length of the gonostylus; gonocoxites fused basally with hypandrium (Figure 14). Gonostylus pilose with long subapical bristle and spine-like bristle at apex (Figure 14); spine-like bristle $0.7 \mathrm{X}$ the length of the gonostylus (Figure 14). Paramere long, 1.8X the length of gonocoxite (Figure 14); paramere with small, apical, inner concavity (Figure 15); paramere with apical pilosity and a long, thin subapical bristle, 0.3X the length of the paramere (Figure 15). Aedeagus bifid (Figure 14). Aedeagal apodeme 1.3X the length of the paramere, with rounded anterior margin (Figure 14).

\section{Discussion}

Bravo (2007) proposed a key to the males of nine known species of Neotropical Sycorax. Another species of Sycorax, S. utriensis Bejarano, Duque \& Vélez, was described by Bejarano et al. (2008), and represents an atypical species of the genus for having a gonostyle without a long terminal spine and with multiple thick spines distributed along this structure. According to the key prepared by Bravo (2007), the two new species segregate with the two Brazilian species of Sycorax, S. longispinosa Bravo and S. assimilis Barretto, which have a gonostylus with only a long apical spine and a long subterminal bristle.

The two new species of Sycorax differs from S. longispinosa by the latter having a paramere with a long bristle, 2.0X the length of the paramere. The paramere of $S$. cariacicaensis Santos \& Bravo sp.

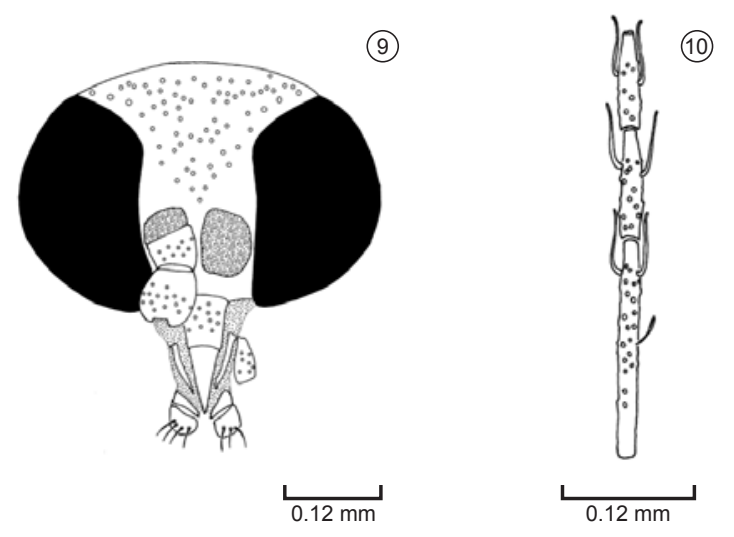

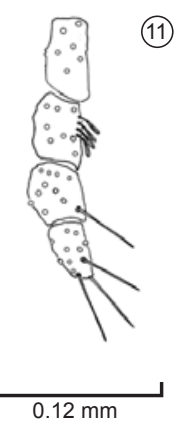

(1)

(13)
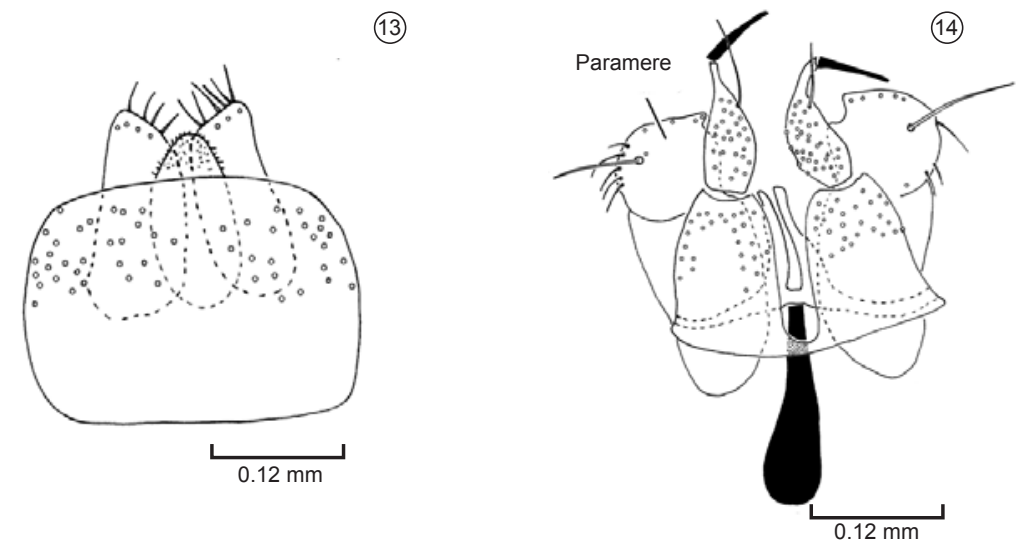

(12)

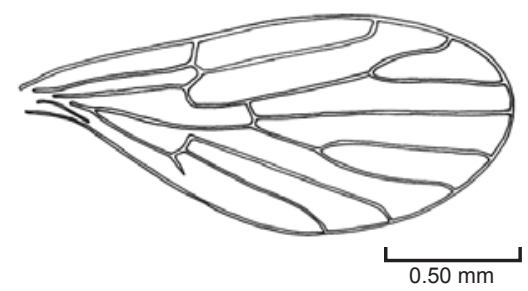

(15)

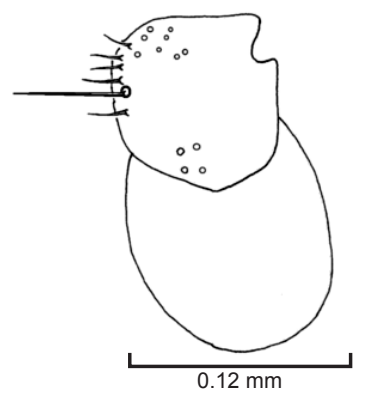

Figures 9-15. Sycorax espiritosantensis Santos \& Bravo sp. nov. Male. Figures 10, 11, 12, 15 from holotype; figures 9, 13, 14 from paratypes. 9. Head, frontal 10. Antenna, flagellomeres 1-3. 11. Palpus. 12. Wing. 13. Male terminalia, dorsal view. 14. Male terminalia, ventral view. 15. Paramere.

Figuras 9-15. Sycorax espiritosantensis Santos \& Bravo sp. nov. Macho. Figuras 10, 11, 12, 15 do holótipo; figures 9, 13, 14 de parátipos. 9. Cabeça. 10. Antena, flagelômeros 1-3. 11. Palpo. 12. Asa. 13. Terminália masculina, vista dorsal. 14. Terminália masculina, vista ventral. 15. Parâmero. 
nov. has a long bristle, but it is only $0.7 \mathrm{X}$ the length of the paramere, while the long bristle of S. espiritosantensis Santos \& Bravo sp. nov. is $0.3 \mathrm{X}$ the length of the paramere.

S. espiritosantensis Santos \& Bravo sp. nov. differs from $S$. assimilis by the relative length of the two basal flagellomeres. In the new species $S$. espiritosantensis, the first flagellomere is $1.8 \mathrm{X}$ the length of the second, while in $S$. assimilis this relationship is $1.5 X$. The relative length of the first flagellomere in $S$. cariacicaensis Santos \& Bravo sp. nov. is $1.5 \mathrm{X}$ the second flagellomere, similar to S. assimilis.

S. cariacicaensis Santos \& Bravo sp. nov. differs from S. assimilis by the relative length of the aedeagus, and the terminal spine of the gonostylus. The aedeagus in S. assimilis reaches the end of the paramere, while in S. cariacicaensis Santos \& Bravo sp. nov. the aedeagus ends anteriorly to the apex of the paramere. Additionally, the apical spine of $S$. cariacicaensis Santos \& Bravo sp. nov. is long (similar to the length of the gonostylus) while in $S$. assimilis it is only $0.5 \mathrm{X}$ the length of the gonostylus.

\section{Acknowledgements}

Freddy Bravo has a research grant of CNPq (306426/2006-4).

\section{References}

BARRETTO, M.P. \& COUTINHO, J.O. 1940. Processos de captura, dissecação e montagem de flebótomos. An. Fac. Med. Univ. São Paulo, 16:173-187.

BARRETTO, M.P. 1956. Sobre o gênero Sycorax Hal., com as descrições de duas novas espécies do Brasil (Diptera, Psychodidae). Folia clin. biol. 26:71-75.
BEJARANO, E.E, DUQUE, P. \& VÉLEZ, I.D. 2008. A new species of Sycorax (Diptera, Psychodidae, Sycoracinae) from the Pacific coast of Colombia. Rev. bras. entomol. 52(1):28-31.

BRAVO, F. 2003. Descrição de Sycorax bahiensis sp. nov. (Diptera, Psychodidae) do Brasil. Rev. bras. zool. 20(3):385-387.

BRAVO, F. 2006. The taxonomy of Neotropical Brunettiina (Diptera, Psychodidae, Psychodinae, Mormiini) with descriptions of ten new species from Brazil and comments on the generic classification of this subtribe. Zootaxa, 1134:1-28.

BRAVO, F. 2007. First record and description of a new species of Sycorax Curtis (Diptera: Psychodidae, Sycoracinae) from the Brazilian Amazon. Neotrop. entomol. 36(4):525-528.

DUCKHOUSE, D.A. 1972. Psychodidae (Diptera, Nematocera) of South Chile, subfamilies Sycoracinae and Trichomyiinae. Trans. R. Entomol, Soc. Lond. 124:231-268.

DUCKHOUSE, D.A. 1990. The Australasian genera of Pericomoid Psychodidae (Diptera) and the status of related Enderlein genera in the Neotropics. Invertebr. taxon. 3(6):721-746.

McALPINE, J.F. 1981. Morphology and terminology: adults. In Manual of Neartic Diptera (J.F. Mcalpine, B.V. Peterson, G.E. Shewell, H.J. Teskey, J.R. Vockeroth \& D.M. Wood, eds.). Research Branch; Agriculture Canada, Ottawa, p. 9-63. Monograph n ${ }^{\circ}$ 27, v. 1.

YOUNG, D.G. 1979. A review of the bloodsucking psychodid flies of Colombia (Diptera: Phlebotominae and Sycoracinae). Institute of Food and Agricultural Sciences; Agricultural Experiment Stations, Gainesville. 266 p. Technical Bulletin 806.

Received 21/10/08

Revised 15/02/09

Accepted 01/04/09 